\title{
PRODUCTIVITY OF IRRIGATED PEANUT PLANTS UNDER PULSE AND CONTINUOUS DRIPPING IRRIGATION WITH BRACKISH WATER ${ }^{1}$
}

\author{
RUANA IRIS FERNANDES CRUZ²*, GERÔNIMO FERREIRA DA SILVA², MANASSÉS MESQUITA DA SILVA², \\ ALAN HENRIQUE SANTOS SILVA², JOSÉ AMILTON SANTOS JÚNIOR ${ }^{2}$, ÊNIO FARIAS DE FRANÇA E SILVA ${ }^{2}$
}

\begin{abstract}
Pulse irrigation may be more advantageous for peanut crops than continuous irrigation, when using brackish water. However, studies on pulse irrigation with brackish water considering the environmental conditions of the Northeast region of Brazil using are incipient. Therefore, the objective of this study was to evaluate the effect of using brackish water for pulse and continuous dripping irrigations on the grain yield and production characteristics of peanut (Arachis hypogaea L.) crops. A completely randomized block design with four repetitions was used, in a $6 \times 2$ factorial arrangement consisted of six electrical conductivities of the irrigation water $\left(\mathrm{EC} ; 0.2,1.6,2.8,4.0,5.2\right.$, and $6.4 \mathrm{dS} \mathrm{m}^{-1}$ ) set by adding $\mathrm{NaCl}$ to the irrigation water, which originally had $0.2 \mathrm{dS} \mathrm{m}^{-1}$, until reaching the respective EC; and two irrigation methods (pulse and continuous). The evaluated variables were fresh and dry weights of shoot, 10 grains, pods, grains, and production; number of pods and grains; and percentages of empty pods (EP\%) and perfect grains ( $\mathrm{PG} \%)$. The addition of salt to the irrigation water negatively affected all variables studied, except for EP\% and PG\%. The lowest EP\% were found for the pulse irrigation, which increased the pod and grain yields, regardless of the EC of the irrigation water. Under the conditions of the present study, the use of brackish waters with electrical conductivities of up to $2.98 \mathrm{dS} \mathrm{m}^{-1}$ is viable for peanut production.
\end{abstract}

Keywords: Arachis hypogaea L. Salinity. Sodium chloride. Pulse irrigation.

\section{PRODUÇÃO DE AMENDOIM IRRIGADO COM ÁGUAS SALOBRAS VIA GOTEJAMENTO PULSADO E CONTÍNUO}

RESUMO - A irrigação por pulsos pode proporcionar maiores rendimentos para a cultura do amendoim em comparação a irrigação contínua com a utilização de águas salobras, contudo, estudos para as condições do Nordeste brasileiro utilizando esta técnica de manejo da irrigação associada ao uso de águas salobras são incipientes. Diante disso, objetivou-se com o trabalho avaliar o efeito do uso de águas salobras e da irrigação por gotejamento pulsado e contínuo sobre a produção de grãos e características produtivas do amendoim (Arachis hypogaea L.). O delineamento experimental utilizado foi o de blocos casualizados, em esquema fatorial de 6 × 2, composto por seis condutividades elétricas da água de irrigação (CEa: 0,2; 1,6; 2,8; 4,0; 5,2 e $6,4 \mathrm{dS} \mathrm{m}^{-1}$ ), na qual foi adicionada $\mathrm{NaCl}$ a água de abastecimento (CEa: $0,2 \mathrm{dS} \mathrm{m}^{-1}$ ) até atingir as respectivas $\mathrm{CEa}$, e duas formas de aplicação da irrigação por gotejamento (com pulsos e contínua), com quatro repetições. As variáveis analisadas foram: a massa fresca e seca da parte aérea de 10 grãos, das vagens, dos grãos e da produção, além do número de vagens, do número de grãos, da percentagem de vagens chochas (PerVC) e da percentagem de grãos perfeitos (PerGP). A salinidade influenciou negativamente todas as variáveis estudadas, com exceção do PerVC e da PerGP. As menores percentagens de vagens chochas foram obtidas com a irrigação pulsada que por sua vez demonstrou a maior produção de vagens e de grãos independentemente dos níveis de condutividade elétrica da água avaliados. Nas condições desta pesquisa, é viável produzir amendoim utilizando águas salobras com condutividade elétrica de até $2,98 \mathrm{dS} \mathrm{m}^{-1}$.

Palavras-chave: Arachis hypogaea L. Salinidade. Cloreto de sódio. Irrigação por pulsos.

\footnotetext{
${ }^{*}$ Corresponding author

${ }^{1}$ Received for publication in 06/05/2020; accepted in 11/09/2020.

Paper extracted from the dissertation of the first author.

${ }^{2}$ Department of Agricultural Engineering, Universidade Federal Rural de Pernambuco, Recife, PE, Brazil; ruanairis@gmail.com - ORCID 0000-0001-8493-0034, agrogefe@yahoo.com.br - ORCID: 0000-0002-3348-7252, manasses.ufrpe@gmail.com - ORCID: 0000-00023892-3076, alan_henriquesilva@outlook.com - ORCID: 0000-0001-5442-0922, eng.amiltonjr@hotmail.com - ORCID: 0000-0002-16567103, enio.fsilva@ufrpe.br - ORCID: 0000-0002-8652-503X.
} 


\section{INTRODUCTION}

Peanut (Arachis hypogaea L.) is the fourth most grown oilseed species in the world due to its high oil, protein, fiber, and vitamin contents. It is a promising species for several purposes, from human and animal food to biofuel production (ARRUDA et al., 2015; ARYA; SALVE; CHAUHAN, 2015).

In Brazil, the peanut production is concentrated in the state of São Paulo, which has approximately $93 \%$ of the Brazilian production $\left(406,500 \mathrm{Mg}\right.$ ) and a yield of $3.73 \mathrm{Mg} \mathrm{ha}^{-1}$ (CONAB, 2020). The Northeastern region has a demand of $50,000 \mathrm{Mg}$ of peanuts (pods) per year and is the second largest consumer region in the country, but presented a production of only $2,000 \mathrm{Mg}$ in the $2018 / 2019$ crop season and a yield of $0.892 \mathrm{Mg} \mathrm{ha}^{-1}$ (CONAB, 2020). These production results in this region may be due to the growth methods used, which are usually in rainfed systems; moreover, they are aggravated by the irregular rainfall distribution, which compromises the production and, consequently, the economic success of the activity (SIZENANDO et al., 2016).

Irrigation is an alternative to supply water to plants and produce peanuts at any time of the year and in locations where the crop water needs are not naturally met. Some irrigation systems promote water use efficiency, such as dripping irrigation, preventing water loss (EID; BAKRY; TAHA, 2013); however, the use of complementary measures to improve water use efficiency is necessary, mainly for areas with natural severe water shortage (BORGES; SILVA, 2011).

In addition, groundwater is frequently used for irrigation in semiarid regions, where these waters usually have high salt concentrations (PAULUS et al., 2012). Techniques such as pulse irrigation are alternatives that reduce water infiltration speed, providing greater moisture in the upper soil layer. Pulse irrigation reduces losses by percolation and the amount of water applied (ZAMORA et al., 2019). This is an efficient irrigation method that provides a higher water use efficiency, without compromising the crop yield (ALMEIDA; LIMA; PEREIRA, 2015).

The pulse irrigation method consists of applying water in fractions (pulses) with short irrigation periods, followed by a period without irrigation and, again, another irrigation period, until the required water depth is supplied (ALMEIDA et al., 2018).

Regarding the use of brackish water, the pulse irrigation may maintain the soil moist for a longer time than other methods, which results in lower salinity in the rhizosphere of a crop, reducing deleterious effects of salts (ASSOULINE et al., 2006). Almeida et al. (2018) reported that the use of pulse irrigation results in higher common bean yield than continuous irrigation, when using brackish water. However, salt stress decreases leaf area, stem diameter, plant height (GRACIANO et al., 2011; SOUSA et al. 2012; SOUSA et al., 2014) and, consequently, shoot dry weight and grain production (CORREIA et al., 2009).

According to Ayers and Westcot (1999), the salinity threshold for peanut crops is $3.2 \mathrm{dS} \mathrm{m}$. However, Correia et al. (2009) evaluated growth, production, and chlorophyll fluorescence of two peanut cultivars, including BR-1, under salt stress conditions and found decreases in number of fruits of $7.3 \%$ per unit of electrical conductivity (EC) increased from $1.095 \mathrm{dS} \mathrm{m} \mathrm{m}^{-1}$, indicating that the peanut yield was affected by EC below $3.2 \mathrm{dS} \mathrm{m}^{-1}$. These results reinforce the importance of developing studies that evaluate the effects of irrigation methods on the productive performance of peanut plants of the cultivar BR-1 when irrigated using waters with EC above and below the salinity threshold of the crop.

Pulse irrigation is a promising technique for regions of water shortage that use brackish water for irrigation, but studies using this method in the Brazilian conditions are incipient. Therefore, the objective of this study was to evaluate the effect of using brackish water for pulse and continuous dripping irrigations on the grain yield and production characteristics of peanut (Arachis hypogaea L.) crops

\section{MATERIAL E METHODS}

A field experiment was conducted from September to November 2019 at the experimental area of the Agricultural Engineering Department of the Federal Rural University of Pernambuco (UFRPE), Sede campus, Recife, PE, Brazil $\left(08^{\circ} 01^{\prime} 05^{\prime \prime} \mathrm{S}, 34^{\circ} 56^{\prime} 48^{\prime \prime} \mathrm{W}\right.$, and average altitude of 6.5 $\mathrm{m})$. The climate of the region is tropical rainy, As" and Ams", according to the Köppen classification, with a rainy season from April to July (SILVA et al., 2012).

Rainfall, mean air temperature, relative air humidity, reference evapotranspiration (ETo), and global radiation in the experimental area during the experiment (Figure 1) were recorded using an automatic weather station (CR1000, CFM100, OS100; Campbell Scientific, Logan, USA) installed adjacent to the area. The rainfall depth during the peanut growth period (planting to harvest) was $103.7 \mathrm{~mm}$ 


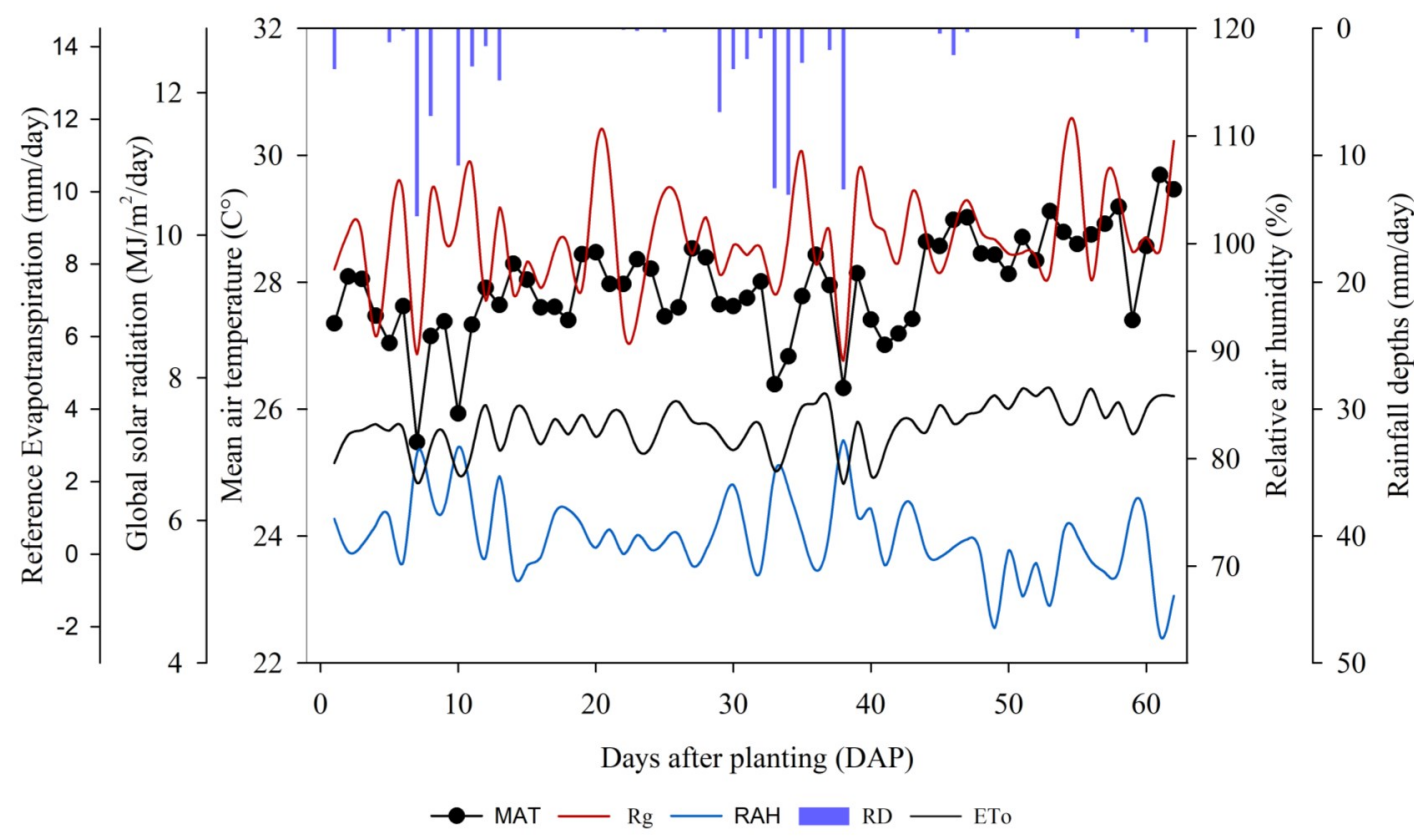

Figure 1. Rainfall depths (RD), mean air temperature (MAT), relative air humidity (RAH), reference evapotranspiration (ETo), and global solar radiation $(\mathrm{Rg})$ during the experiment.

The experimental area had 48 circular drainage lysimeters with a capacity for $240 \mathrm{~L}$ each, with outer top diameter of $0.50 \mathrm{~m}$ and $0.7 \mathrm{~m}$ height, spaced $1.0 \mathrm{~m}$ apart, and lysimeter boxes at $0.40 \mathrm{~m}$ above the ground.

A layer with gravel (25 $\mathrm{mm}$ granulometry) was added to each lysimeter, totaling a volume of 1.2 $\mathrm{m}^{3}$ for the 60 lysimeters, to facilitate the drainage through the drain cover. A geotextile blanket was added to the upper face of the gravel layer to retain particles from the upper layer (soil) to the lower layer and the drainage system. The drainage system consisted of a 0.5 -inch hose adapter at the base of the lysimeter connected to a low-density polyethylene tube (LDPE PN 30 DN $16 \mathrm{~mm}$ ) and a 2-liter PET bottle.

The soil used to fill the lysimeters was classified as a Spodosol (Espodossolo, according to the Brazilian Soil Classification System; SANTOS et al., 2013). The collected soil was from the 0 to $40 \mathrm{~cm}$ layer. It had a sand texture (952 $\mathrm{g} \mathrm{kg}^{-1}$ sand, $22 \mathrm{~g} \mathrm{~kg}^{-1}$ silt, and $26 \mathrm{~g} \mathrm{~kg}^{-1}$ clay); soil and particle densities at the beginning of the experiment of 1.50 and $2.65 \mathrm{~kg} \mathrm{dm}^{-3}$, respectively; and total porosity of $43.6 \%$. The soil water storage limit was measured using a Richards' pressure chamber, and the values obtained were $0.033 \mathrm{~m}^{3} \mathrm{~m}^{-3}$ and $0.022 \mathrm{~m}^{3} \mathrm{~m}^{-3}$ for field capacity $(10 \mathrm{kPa})$ and permanent wilting point $(1500 \mathrm{kPa})$, respectively.

The soil chemical analysis was carried out before the implementation of the experiment, according to methodological procedures described by Embrapa (2011), and showed the following results: $\mathrm{pH}$ in water $(1: 2.5)=6.5 ; \mathrm{Ca}^{2+}, \mathrm{Mg}^{2+}, \mathrm{Al}^{3+}$, $\mathrm{Na}^{+}$and $\mathrm{K}^{+}=1.75,0.55,0.0,0.08$, and $0.07 \mathrm{cmol}_{\mathrm{c}}$ $\mathrm{dm}^{-3}$, respectively; $\mathrm{P}=5.03 \mathrm{mg} \mathrm{dm}^{-3}$, organic matter $=5.53 \mathrm{~g} \mathrm{~kg}^{-1}, \mathrm{H}+\mathrm{Al}$, sum of bases, cation exchange capacity, and effective cation exchange capacity = $0.69,2.45,3.14$, and $2.45 \mathrm{cmol}_{\mathrm{c}} \mathrm{dm}^{-3}$, respectively; $\mathrm{Cu}, \mathrm{Fe}, \mathrm{Mn}$, and $\mathrm{Zn}=0.1,4.0,4.1$, and $1.3 \mathrm{mg} \mathrm{dm}^{-3}$, respectively; and base saturation, exchangeable sodium, and $\mathrm{EC}=78.03,2.55 \%$, and $0.15 \mathrm{dS} \mathrm{m} \mathrm{m}^{-1}$, respectively.

A chemical analysis of the local public water was carried out before the implementation of the experiment, following methodological procedures recommended by the American Public Health Association (2012), and presented the following results: $\mathrm{pH}=6.30 ; \mathrm{EC}=0.2 \mathrm{dS} \mathrm{m}^{-1} ; \mathrm{K}, \mathrm{Ca}, \mathrm{Mg}, \mathrm{Na}$, Ammonia, Nitrate, Alkalinity, and Chlorides $=2.50$, $0.90,0.60,5.40,0.0,0.02,11.70$, and $15.40 \mathrm{mg} \mathrm{L}^{-1}$, respectively. According to the results, the water was classified as C1S1 (RICHARDS, 1954).

Mineral fertilization with $\mathrm{N}, \mathrm{P}, \mathrm{K}$ at sowing was carried out as recommended by Ribeiro, Guimarães, and Alvarez (1999), using $15 \mathrm{~kg} \mathrm{ha}^{-1}$ of $\mathrm{N}$ (ammonium sulfate; saline index of 3.25), $80 \mathrm{~kg} \mathrm{ha}^{-1}$ of $\mathrm{P}_{2} \mathrm{O}_{5}$ using simple superphosphate (salt partial index of 0.43 ), and $30 \mathrm{~kg} \mathrm{ha}^{-1}$ of $\mathrm{K}_{2} \mathrm{O}$ (potassium chloride; salt index of 1.94). In addition, $15 \mathrm{~kg} \mathrm{ha}^{-1}$ of $\mathrm{N}$ and $30 \mathrm{~kg} \mathrm{ha}^{-1}$ of $\mathrm{K}_{2} \mathrm{O}$ was applied as topdressing at 15 days after emergence of plants. Lime application to correct the soil $\mathrm{pH}$ and organic fertilizer application were not necessary for the experiment. Micronutrients were applied at 20 days after planting, using a foliar fertilizer (Agross; Amino, Campinas, Brazil), following the manufacturer recommendation for peanut crops.

A completely randomized block design with four repetitions was used, in a $6 \times 2$ factorial 
arrangement consisted of six electrical conductivities of the irrigation water (EC; 0.2, 1.6, 2.8, 4.0, 5.2, and $6.4 \mathrm{dS} \mathrm{m}^{-1}$ ) and two irrigation methods (pulse and continuous).

These EC levels were chosen to provide equal intervals up to the highest EC was twice the salinity threshold for the crop, which was established by Ayers and Westcot (1999), $3.2 \mathrm{dS} \mathrm{m}^{-1}$. The EC levels were set by adding sodium chloride $\mathrm{NaCl}$ to the irrigation water, which was collected from local public water at the UFRPE and had EC $0.2 \mathrm{dS} \mathrm{m}^{-1}$, until reaching the respective EC. The local public water was used as a control treatment $\left(0.2 \mathrm{dS} \mathrm{m}^{-1}\right)$, without addition of salt.

A dripping irrigation system was used; it was composed of six 500-liter reservoirs, filter disks, centrifugal electric pumps with horizontal axis (3.7 $\mathrm{kW}$ ), solenoid-type valves, control with panel Arduino-type controller, 16-channel relay module, 10-amperes honeycomb switch, a RTC DS3231 Real Time Clock, a 0.5 -inch threaded vacuum valve, and self-compensating drippers with a nominal flow of $2 \mathrm{~L} \mathrm{~h}^{-1}$ paired to each lysimeter spaced $0.20 \mathrm{~m}$ apart and totaling a flow of $4 \mathrm{~L} \mathrm{~h}^{-1}$. The service pressure was set to 10 meters of water gauge through a pressure gauge; the flow was measured using flow tests.

The water was distributed through lowdensity polyethylene tubes (LDPE NP 30 ND 16 $\mathrm{mm}$ ); each central line contained 4 branches that served the respective plots. The irrigation water depth, which was applied to the plants every two days, was determined as the amount of water required to maintain the soil moisture at field capacity, considering the soil density and the root system depth, according to the methodology of Mantovani, Bernardo and Palaretti (2009). The soil moisture was determined on days that the irrigation was carried out using the microwave technique proposed by Tavares et al. (2009).

The efficiency of the system was established at $90 \%$, and the application time was defined according to the need for each treatment; this time was divided into 5 equal parts ( 5 pulses) with onehour intervals between applications (pulses) for the treatments with pulse irrigation. The application of brackish waters started at 12 days after emergence of plants, when the plants were fully established.

The peanut cultivar BR-1 is an early maturation variety launched in 1994, with average cycle of 90 days. It belongs to the subspecies $A$. hypogaea fastigiata and presents good adaptation to the climate of the Semiarid region of Brazil (GRACIANO et al., 2011). This cultivar is recommended for crops intended to fresh consumption and has productive potentials of $3.8 \mathrm{Mg}$ $\mathrm{ha}^{-1}$ under irrigated systems, and $1.7 \mathrm{Mg} \mathrm{ha}^{-1}$ under rainfed conditions; the grains present oil and protein contents of $45 \%$ and $38 \%$, respectively (EMBRAPA, 2009). Six seeds were sown to a depth of $5 \mathrm{~cm}$ in each lysimeter to ensure germination. A thinning was carried out at 10 days after emergence of plants, keeping one plant per lysimeter (one plant per plot).

Phytosanitary monitoring and cultural managements were carried out according to recommendations described by EMBRAPA (2009). Harvesting was carried out when the plants in the treatment with the highest EC reached physiological maturation, which was at 63 days after planting.

The evaluated variables were fresh and dry weights of shoot, 10 grains, pods, grains, and production; number of pods and grains; and percentages of empty pods $(\mathrm{EP} \%)$ and perfect grains (PG\%). Shoot fresh weight was measured considering the leaf and stem weights; EP\% and PG\% were summed to obtain the production fresh weight. The samples were taken to an oven until constant weight to obtain the dry weights of shoot, pods, grains, and 10 grains. The number of pods and grains were counted, and the $\mathrm{EP} \%$ relative to the total number of pods was calculated for each treatment. The $\mathrm{PG} \%$ was calculated by the ratio between the number of perfect grains and the total number of grains of each plant.

The data were subjected to normality and homoscedasticity tests and analysis of variance by the $\mathrm{F}$ test; significant means were subjected to regression analysis (salinity levels) and the means (irrigation methods) were compared by the ScottKnott test at $5 \%$ probability, using the SISVAR program (FERREIRA, 2011).

\section{RESULTS E DISCUSSION}

All variables were significantly affected by the irrigation methods (pulse and continuous) and electrical conductivities (EC; 0.2, 1.6, 2.8, 4.0, 5.2, and $6.4 \mathrm{dS} \mathrm{m}^{-1}$ ) used, except for the percentage of empty pods $(\mathrm{EP} \%)$, which was significantly affected only by the irrigation methods, and the percentage of perfect grains (PG\%), which was not significantly affected by any of the treatments (Table 1).

The effects of the irrigation methods and EC on the shoot fresh weight (Figure 2A), pod fresh weight (Figure 2B), grain fresh weight (Figure 2C), and production fresh weight (Figure 2D) showed that shoot fresh weight decreased $15.7 \mathrm{~g}$ per plant for each unit of EC increased, reaching an estimated value of $270.1 \mathrm{~g}$ per plant at the EC of $0.2 \mathrm{dS} \mathrm{m}^{-1}$, which was $36.1 \%$ higher than that found for the EC of $6.4 \mathrm{dS} \mathrm{m}^{-1}$. This difference was probably due to the deleterious effects of salt stress on plants, which may have hindered water and nutrient absorptions. According to Sá et al. (2020), the excessive absorption of chloride and sodium ions due to saline conditions causes toxicity, and physiological, nutritional, and hormonal changes to plants, affecting the synthesis and accumulation of photoassimilates and, consequently, the plant growth and production. 
Table 1. Analysis of variance for fresh and dry weights of shoot, pods, grains, production (pods and grains), and 10 grains, number of grains, number of pods, and percentages of empty pods and perfect grains.

\begin{tabular}{|c|c|c|c|c|c|c|}
\hline \multirow{3}{*}{ Source of variation } & \multirow{3}{*}{ Degrees of freedom } & \multicolumn{5}{|c|}{ Mean Square } \\
\hline & & \multicolumn{5}{|c|}{ Fresh weight } \\
\hline & & Shoot & Pods & Grains & Production & 10 grains \\
\hline Irrigation method $(\mathrm{M})$ & 1 & $34122 * *$ & $1257 * *$ & $405.83 * *$ & $3091.55^{* *}$ & $8.76^{* *}$ \\
\hline $\begin{array}{l}\text { Electrical conductivity } \\
\text { (EC) }\end{array}$ & 5 & $10712 * *$ & $155.23 * *$ & $378.62 * *$ & $1017.92 * *$ & $4.57 * *$ \\
\hline $\mathrm{M} \times \mathrm{EC}$ & 5 & $68.15^{\text {ns }}$ & $1.64^{\mathrm{ns}}$ & $1.82^{\mathrm{ns}}$ & $3.63^{\mathrm{ns}}$ & $0.01^{\mathrm{ns}}$ \\
\hline Block & 3 & $944.71^{\mathrm{ns}}$ & $46.01^{\mathrm{ns}}$ & $5.18^{\mathrm{ns}}$ & $52.72^{\text {ns }}$ & $1.81 * *$ \\
\hline Residue & 33 & 378.96 & 19.38 & 5.75 & 28.49 & 0.31 \\
\hline $\mathrm{CV}$ & $\%$ & 8.82 & 10.91 & 9.28 & 8.06 & 14.50 \\
\hline \multirow{2}{*}{ Source of variation } & \multirow{2}{*}{ Degrees of freedom } & \multicolumn{5}{|c|}{ Dry weight } \\
\hline & & Shoot & Pods & Grains & Production & 10 grains \\
\hline Irrigation method (M) & 1 & $1153.07 * *$ & $96.31 * *$ & $176.03 * *$ & $532.75^{* *}$ & $2.62 * *$ \\
\hline $\begin{array}{l}\text { Electrical conductivity } \\
\text { (EC) }\end{array}$ & 5 & $1094.47 * *$ & $19.17 * *$ & $87.25^{* *}$ & $187.52^{* *}$ & $1.86^{* *}$ \\
\hline $\mathrm{M} \times \mathrm{EC}$ & 5 & $6.09^{\mathrm{ns}}$ & $0.19^{\text {ns }}$ & $0.15^{\mathrm{ns}}$ & $0.22^{\mathrm{ns}}$ & $0.006^{\mathrm{ns}}$ \\
\hline Block & 3 & $53.68^{*}$ & $1.33^{\mathrm{ns}}$ & $1.30^{\mathrm{ns}}$ & $4.62^{\mathrm{ns}}$ & $0.265^{\mathrm{ns}}$ \\
\hline Residue & 33 & 13.59 & 0.56 & 1.33 & 1.92 & 0.13 \\
\hline $\mathrm{CV}$ & $\%$ & 6.34 & 7.41 & 9.33 & 6.17 & 21.34 \\
\hline \multirow[b]{2}{*}{ Source of variation } & \multirow[b]{2}{*}{ Degrees of freedom } & \multicolumn{5}{|c|}{ Production } \\
\hline & & $\begin{array}{l}\text { Number of } \\
\text { pods }\end{array}$ & $\begin{array}{l}\text { Number of } \\
\text { grains }\end{array}$ & \multicolumn{2}{|c|}{$\begin{array}{l}\text { Percentage of } \\
\text { empty pods }\end{array}$} & $\begin{array}{l}\text { Percentage of } \\
\text { perfect grains }\end{array}$ \\
\hline Irrigation method (M) & 1 & $5940.75^{* *}$ & $1250.52 * *$ & \multicolumn{2}{|c|}{$856.83^{* *}$} & $10.64^{\mathrm{ns}}$ \\
\hline $\begin{array}{l}\text { Electrical conductivity } \\
\text { (EC) }\end{array}$ & 5 & $1325^{* *}$ & $335.47 * *$ & \multicolumn{2}{|c|}{$11.151^{\mathrm{ns}}$} & $42.04^{\mathrm{ns}}$ \\
\hline $\mathrm{M} \times \mathrm{EC}$ & 5 & $2.45^{\mathrm{ns}}$ & $0.67^{\mathrm{ns}}$ & \multicolumn{2}{|c|}{$23.38^{\mathrm{ns}}$} & $24.26^{\mathrm{ns}}$ \\
\hline Block & 3 & $418.28 * *$ & $271.68 * *$ & \multicolumn{2}{|c|}{$1225.65^{\mathrm{ns}}$} & $57.37^{\mathrm{ns}}$ \\
\hline Residue & 33 & 19.40 & 3.43 & \multicolumn{2}{|c|}{15.34} & 40.28 \\
\hline $\mathrm{CV}$ & $\%$ & 5.89 & 4.93 & \multicolumn{2}{|c|}{29.20} & 6.58 \\
\hline
\end{tabular}

$* *=$ significant at $1 \%$ probability $*$ * significant at $5 \%$ probability $; \mathrm{ns}=$ not significant 

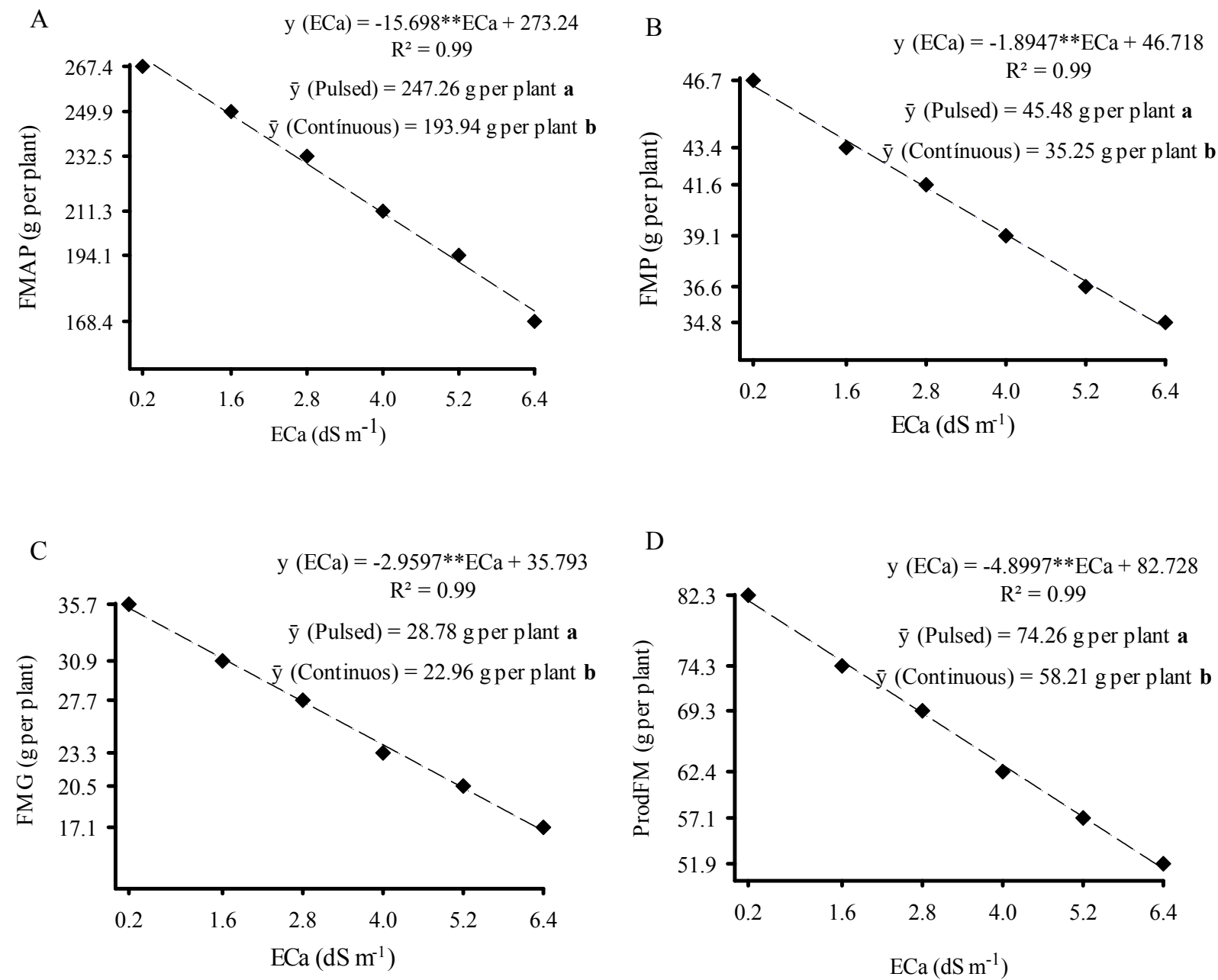

Means for irrigation methods (pulse and continuous) followed by different letters are significantly different by the Scott Knott test $(p<0.05)$.

Figure 2. Shoot fresh weight (SFW) (A), pod fresh weight (PFW (B), grain fresh weight (GFW) (C), and production fresh weight (PFW) (D) of peanut plants of the cultivar BR-1 as a function of electrical conductivities of the irrigation water (EC) and irrigation methods.

The use of pulse irrigation resulted in a shoot fresh weight $27.5 \%$ higher than the use of continuous irrigation (Figure 2A). This result was due to the partitioning of the water depth applied when using the pulse irrigation method, which maintains the soil moisture for a longer time. It also results in less losses by evaporation and in a greater available water content to supply the physiological processes of plants; this higher water absorption and photosynthesis affect the dry matter growth and accumulation (ALMEIDA et al., 2018; ZAMORA et al., 2019).

Pod fresh weight decreased approximately 1.9 g per plant for each unit of EC increased (Figure 2B); the highest estimated pod fresh weight (46.3 g per plant) was with the EC of $0.2 \mathrm{dS} \mathrm{m}^{-1}$, which was $25.3 \%$ lower than that found with the EC of $6.4 \mathrm{dS} \mathrm{m}^{-1}$ (34.6 g per plant). In addition, plants under pulse irrigation had a pod fresh weight $29.0 \%$ higher than those under continuous irrigation (Figure 2B). A better performance for pulse irrigation method when compared to the continuous method was also found by Abuarab, El-Mogy, and Lotfy (2011), and Eid, Barkry, and Taha (2013).

The grain fresh weight data fitted to a decreasing linear model (Figure 2C), with a reduction of $3 \mathrm{~g}$ per plant for each unit of EC increased, showing a variation of $52.1 \%$ between the EC of 0.2 and $6.4 \mathrm{dS} \mathrm{m}^{-1}$. This denotes that the formation and development of the peanut grains were compromised by the increases in salinity of the irrigation water. Production losses caused by increases in salinity were also found by Correia et al. (2009) for peanut plants of the cultivar BR-1, and by Tagliaferre et al. (2018) for cowpea plants. The use of the pulse irrigation method resulted in a grain fresh weight $25.3 \%$ higher than the use of continuous irrigation. 
The production fresh weight decreased $4.9 \mathrm{~g}$ per plant for each unit of EC increased (Figure 2D), presenting an estimated production of $81.7 \mathrm{~g}$ per plant with the lowest EC $\left(0.2 \mathrm{dS} \mathrm{m}^{-1}\right)$, which was $37.1 \%$ higher than that found with the EC of $6.4 \mathrm{dS} \mathrm{m}^{-1}$. This is associated with the need for plants to spend more energy for water absorption processes and biochemical adjustments necessary for their survival, which is an energy that could be used for plant growth and production (SILVA et al., 2015).

The use of the pulse irrigation method resulted in a production fresh weight $27.57 \%$ higher (16.05 g per plant) than the use of continuous irrigation (Figure 2D). Abuarab, El-mogy, and Lotfy (2011) found fresh weight of green bean pods $180 \%$ higher (Phaselous vulgaris L.) when using pulse irrigation compared to the use of continuous irrigation.

Figures 3A, 3B, 3C, and 3D show the effects of irrigation methods and EC, respectively, on 10grain fresh weight, shoot dry weight, pod dry weight, and grain dry weight of peanuts plants.
A

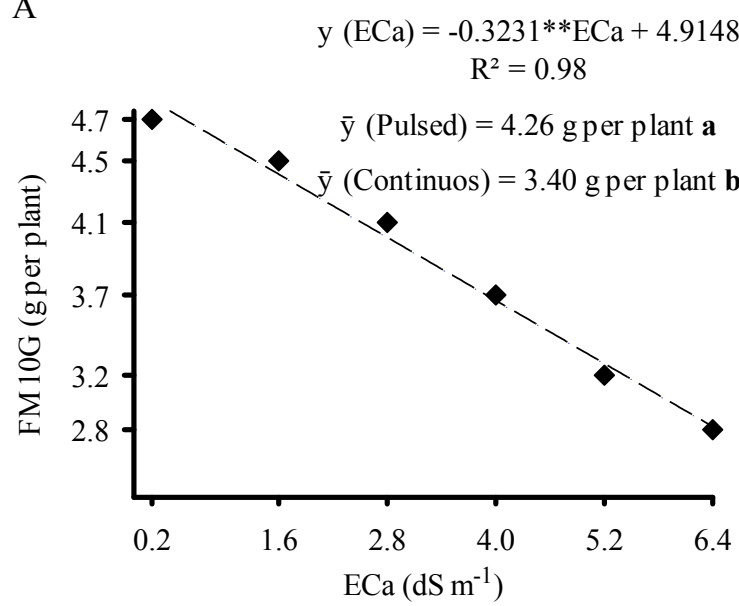

$\begin{aligned} & \mathrm{y}(\mathrm{ECa})=-0.6626^{* *} \mathrm{ECa}+12.281 \\ & \mathrm{R}^{2}=0.98\end{aligned}$

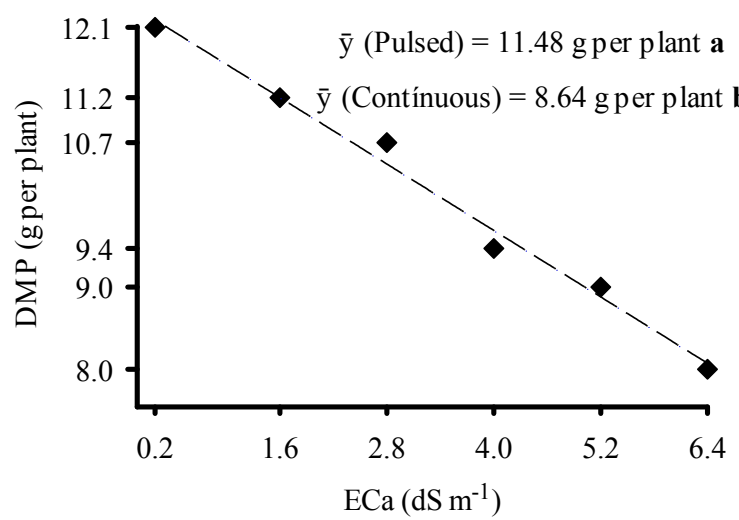

B

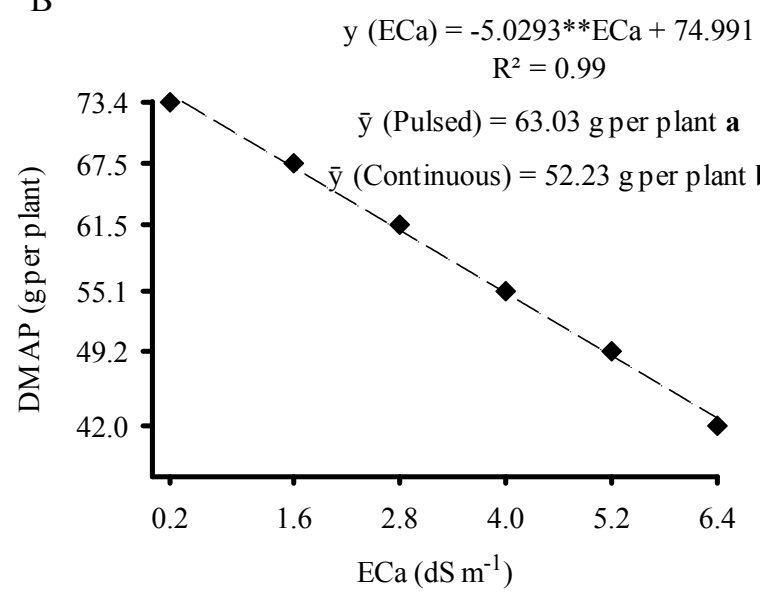

$\mathrm{D}$
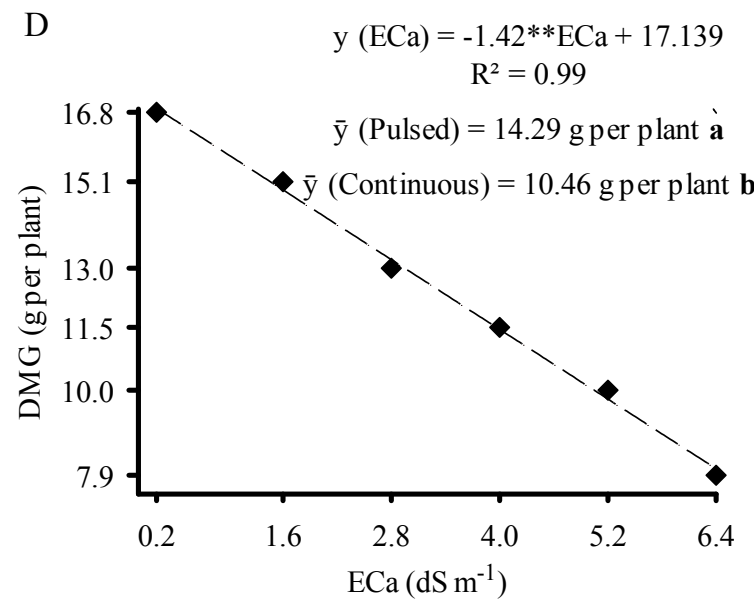

Means for irrigation methods (pulse and continuous) followed by different letters are significantly different by the Scott Knott test $(p<0.05)$.

Figure 3. 10-grain fresh weight (10-GFW) (A), shoot dry weight (SDW) (B), pod dry weight (PDW) (C), and grain dry weight (GDW) (D) of peanut plants of the cultivar BR-1 as a function of salinity levels and irrigation methods. Different letters indicate significant differences between irrigation methods (pulse and continuous) by the Scott Knott test $(p<0.05)$.

The 10-grain fresh weight decreased $0.32 \mathrm{~g}$ per plant for each unit of EC increased (Figure 3A), showing a value of $4.8 \mathrm{~g}$ per plant with the $\mathrm{EC}$ of
$0.2 \mathrm{dS} \mathrm{m}^{-1}$, which was $41.7 \%$ lower than that found with the EC of $6.4 \mathrm{dS} \mathrm{m} \mathrm{m}^{-1}$. This confirms the deleterious effects of excess $\mathrm{NaCl}$ in the irrigation 
water on peanut production. The use of pulse irrigation resulted in a 10 -grain fresh weight $25.3 \%$ higher than that using continuous irrigation (Figure 3A).

According to Correia et al. (2009), these results are due to decreases in photosynthetic surface caused by lower water and nutrient absorptions in plants grown under saline irrigation, which affect the number and weight of fruits.

Shoot dry weight decreased $5.0 \mathrm{~g}$ per plant for each unit of EC increased (Figure 3B), presenting the highest estimated value of $74.0 \mathrm{~g}$ per plant with the lowest EC $\left(0.2 \mathrm{dS} \mathrm{m}^{-1}\right)$, which was $42.2 \%$ higher than the lowest value of $42.8 \mathrm{~g}$ per plant found with the EC of $6.4 \mathrm{dS} \mathrm{m}^{-1}$. The use of pulse irrigation resulted in a shoot dry weight $20.7 \%$ higher than the use of continuous irrigation.

Correia et al. (2009) evaluated shoot dry weight of peanuts of the cultivar BR-1 under EC from 0.4 to $6.0 \mathrm{dS} \mathrm{m}^{-1}$ and found a linear decrease of $6.61 \mathrm{~g}$ per plant for each unit of EC increased. Sousa et al. (2012) found decreases in shoot dry weight of peanut crops caused by increases in salinity of the irrigation water.

Pod dry weight presented a linear decrease as the EC was increased (Figure 3C), with a decrease of $0.66 \mathrm{~g}$ per plant for each unit of EC increased. The highest estimated value of $12.1 \mathrm{~g}$ per plant was found with the EC of $0.2 \mathrm{dS} \mathrm{m}^{-1}$, which was $33.9 \%$ higher than that found with the EC of $6.4 \mathrm{dS} \mathrm{m}^{-1}$. The use of pulse irrigation resulted in a pod dry weight $32.9 \%$ higher than the use of continuous irrigation.

The grain dry weight presented a linear decrease (Figure 3D), with decreases of $1.42 \mathrm{~g}$ per plant for each unit of EC increased. The highest estimated grain dry weight (16.8 g per plant) was found for the EC of $0.2 \mathrm{dS} \mathrm{m}^{-1}$, which was $52.2 \%$ higher than that found for the EC of $6.4 \mathrm{dS} \mathrm{m}^{-1}$. The use of pulse irrigation resulted in a grain dry weight $36.6 \%$ higher than the use of continuous irrigation.

Grain fresh weight (Figure 2C) and grain dry weight (Figure 3D) were the variables most affected by the EC of the irrigation water, presenting losses greater than 50\%. According to Correia et al. (2009), the tolerance of crops to salt stress must be evaluated using variables that present high decreases per increase in the EC of the irrigation water. Therefore, grain fresh weight and grain dry weight can be used for analysis of tolerance. Moreover, according to Correia et al. (2009), decreases in production of $20 \%$ for peanut crops grown using brackish water are relatively small and, therefore, acceptable. Thus, the production found in the present study was satisfactory with EC levels of up to $2.58 \mathrm{dS} \mathrm{m}^{-1}$ for grain fresh weight, and with EC levels up to $2.57 \mathrm{dS} \mathrm{m}^{-1}$ for grain dry weight, which are similar values to those found by Correia et al. (2009).

The effect of irrigation methods and EC levels on the production dry weight, 10-grain dry weight, number of pods, and number of grains is shown in Figures 4A, 4B, 4C, and 4D, respectively.

The production dry weight decreased $2.08 \mathrm{~g}$ per plant for each unit of EC increased, and the highest estimated value was $29 \mathrm{~g}$ per plant found with the EC of $0.2 \mathrm{dS} \mathrm{m}^{-1}$, which was $44.8 \%$ higher than that found with the EC of $6.4 \mathrm{dS} \mathrm{m}^{-1}$ (16.0 g per plant) (Figure 4A). According to EMBRAPA (2009), the average yield for irrigated peanut crops of the cultivar BR-1 in the states of Pernambuco and Sergipe, Brazil, is 26.7 g per plant, which is lower than those found with the treatment without salt stress in the present study. According to the results of the present study, this average yield would be possible with an estimated EC of up to $1.3 \mathrm{dS} \mathrm{m} \mathrm{m}^{-1}$; and, considering production losses lower than $20 \%$, a yield of $23.2 \mathrm{~g}$ per plant would be possible using an $\mathrm{EC}$ of the irrigation water of $2.98 \mathrm{dS} \mathrm{m}^{-1}$.

Similar losses in production dry weight (Figure 4A) were found by Santos et al. (2012) for irrigated peanut crops of the cultivar BR-1 under different salinity levels and leaching fractions, with $0.59 \mathrm{~g}$ per unit of EC increased, presenting the highest loss with the highest EC used $\left(6.4 \mathrm{dS} \mathrm{m}^{-1}\right)$, which was $52.4 \%$ relative to the control treatment $\left(0.2 \mathrm{dS} \mathrm{m}^{-1}\right)$

The use of pulse irrigation resulted in a production dry weight $34.9 \%$ higher than the use of continuous irrigation, representing an increase of $6.67 \mathrm{~g}$ (Figure 4A). The pulse irrigation provided considerable production gains (over 30\%); this indicates the high efficiency of the irrigation method and denotes that it is a promising tool for peanut production, especially under adverse conditions.

The 10-grain dry weight (Figure 4B) decreased $0.21 \mathrm{~g}$ per plant for each unit of EC increased, presenting an estimated value of $2.3 \mathrm{~g}$ per plant with the EC of $0.2 \mathrm{dS} \mathrm{m}^{-1}$, which was $56.5 \%$ higher than that found with the EC of $6.4 \mathrm{dS} \mathrm{m}^{-1}(1.0$ $\mathrm{g}$ per plant). Correia et al. (2009) also found negative effect of salt stress on 10-grain weight of peanuts, but with a reduction of $78.3 \%$ for the highest EC. The use of pulse irrigation resulted in a 10-grain dry weight $32.9 \%$ higher than the use of continuous irrigation, denoting the effectiveness of pulse irrigation for peanut crops (Figure 4B).

The number of pods decreased approximately 2.8 pods per plant for each unit of EC increased (Figure 4C). The lowest number of pods (29.1 pods per plant) was found with the highest EC (6.4 $\mathrm{dS} \mathrm{m}^{-1}$ ), which was $37.4 \%$ higher than that found with the lowest $\mathrm{EC}\left(0.2 \mathrm{dS} \mathrm{m}^{-1}\right)$ (approximately 46.5 pods per plant). The use of pulse irrigation resulted in number of pods $34.5 \%$ higher than the use of continuous irrigation (Figure $4 \mathrm{C})$. 
A

$$
\begin{gathered}
\mathrm{y}(\mathrm{ECa})=-2.0825 * * \mathrm{ECa}+29.419 \\
\mathrm{R}^{2}=0.99
\end{gathered}
$$

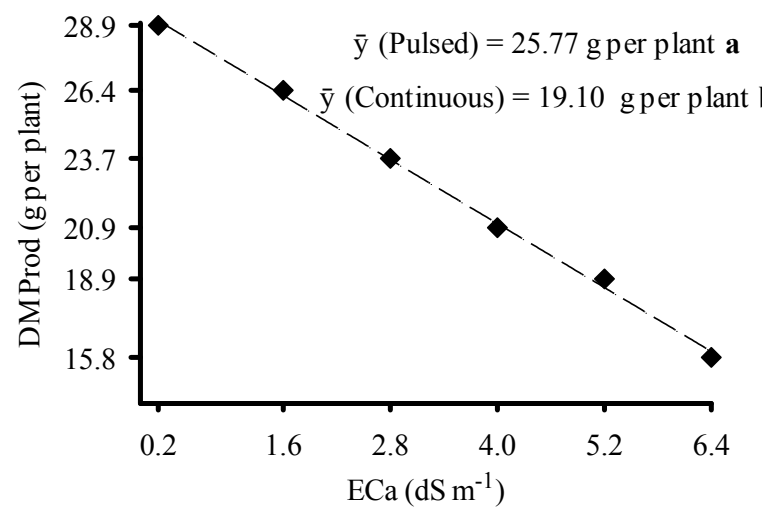

C

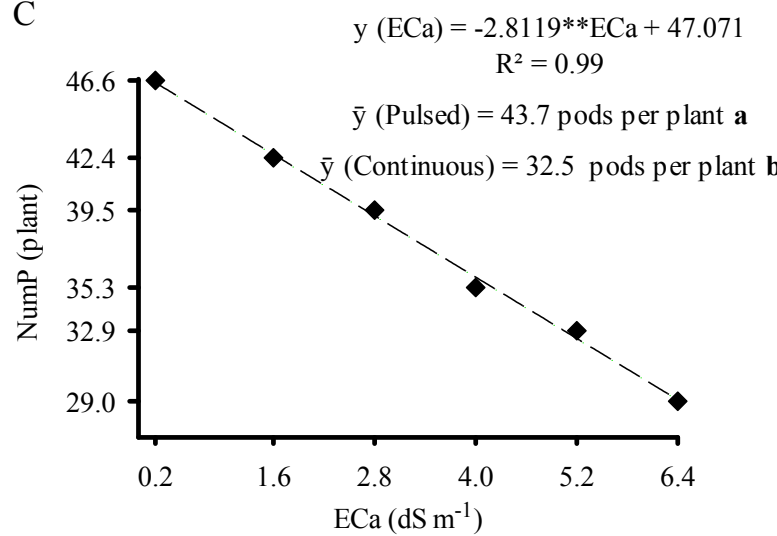

$\mathrm{B}$

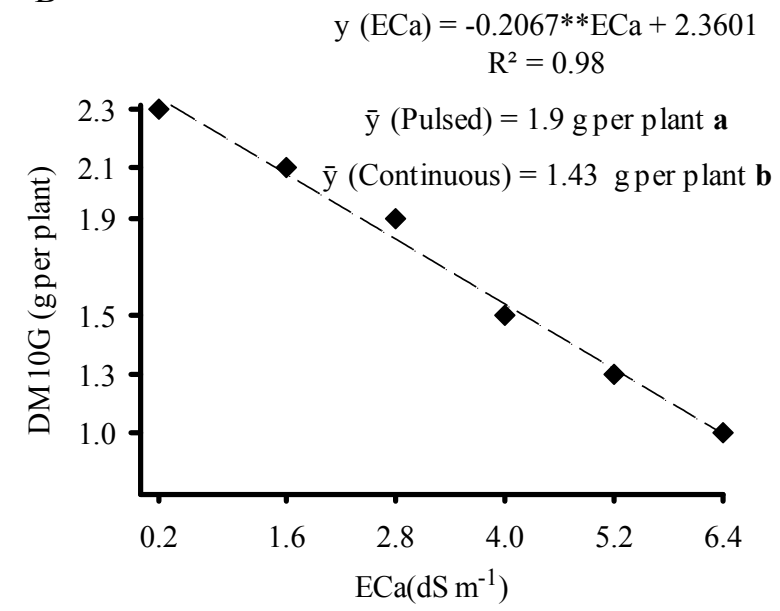

$\mathrm{D}$

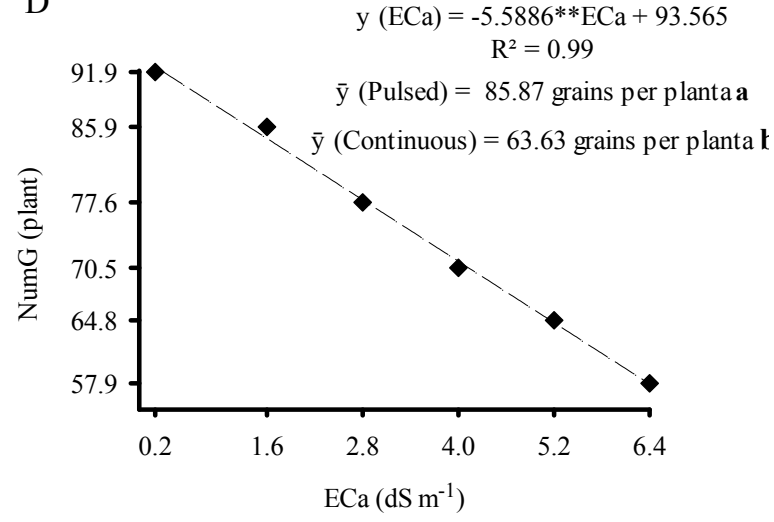

Means for irrigation methods (pulse and continuous) followed by different letters are significantly different by the Scott Knott test $(p<0.05)$.

Figure 4. Production dry weight (PDW) (A), 10-grain dry weight (10-GDW) (B), number of pods (NP) (C), and number of grains (NG) (D) of peanut plants of the cultivar BR-1 depending on salinity levels of the irrigation water and irrigation methods.

According to EMBRAPA (2009), the average number of pods per plant of peanut plants of the cultivar BR-1 is 27 . In the present study, the plants presented values above this average (29.1 pods per plant) even with the highest EC used $\left(6.4 \mathrm{dS} \mathrm{m}^{-1}\right)$. The pod weight and grain weight indicated by the EMBRAPA (2009) is 148 grams for 100-pod weight (1.48 g per pod) and $48 \mathrm{~g}$ for 100 -grain weight $(0.48$ g per grain).

The average pod and grain weights found were $0.26 \mathrm{~g}$ per pod and 0.23 per grain, respectively, with the lowest EC $\left(0.2 \mathrm{dS} \mathrm{m}^{-1}\right)$; and $0.56 \mathrm{~g}$ per pod and $0.1 \mathrm{~g}$ per grain with the highest EC $\left(6.4 \mathrm{dS} \mathrm{m}^{-1}\right)$. Thus, despite the higher number of pods, the grains presented lower weights. Correia et al. (2009) found a decrease of $36.0 \%$ in number of pods for the EC of $6.0 \mathrm{dS} \mathrm{m}^{-1}$.

The number of grains decreased 5.6 grains per plant for each unit of EC increased (Figure 4D). The highest number of grains ( 92.4 grains per plant) was found with the EC of $0.2 \mathrm{dS} \mathrm{m}^{-1}$ and the smallest (57.8 grains per plant) was found with the EC of $6.4 \mathrm{dS} \mathrm{m}^{-1}$. The use of pulse irrigation resulted in number of grains $34.9 \%$ higher than the use of continuous irrigation (Figure 4D).

The high salinity of the irrigation water caused negative effects on all variables evaluated, except for $\mathrm{EP} \%$ and $\mathrm{PG} \%$, which were not affected by the evaluated EC. According to Hasanuzzaman et al. (2016), high salt concentration in the rhizosphere causes ionic, water, and osmotic imbalances, negatively affecting seed growth and root nodulation and quality, which decreases crop yields.

The use of pulse irrigation resulted in a lower $\mathrm{EP} \%(9.19 \%)$ than the use of continuous irrigation $(17.64 \%)$, denoting the greater susceptibility of 
plants to pod malformation when they are irrigated with brackish water using continuous irrigation. According to EMBRAPA (2009), the average EP\% of the peanut cultivar BR-1 is $12 \%$; in the present stu$\mathrm{dy}$, a lower EP\% was found for plants under pulse irrigation $(9.19 \%)$, and the continuous irrigation resulted in an EP\% of $17.64 \%$, which was $5.64 \%$ higher than the average described by the EMBRAPA (2009).

A better performance of the pulse irrigation method, when compared to the continuous irrigation, was found for all variables evaluated, except for PG\%. This indicates that the pulse irrigation method improved the peanut production and promoted substantial yield gains for the crop under the study conditions.

\section{CONCLUSION}

The grain production and productive characteristics of peanut plants of the cultivar BR-1 were negatively affected by the electrical conductivity of the irrigation water, except for the percentages of empty pods and perfect grains.

The productions of pods and grains of peanut plants of the cultivar BR-1 under pulse irrigation were higher than those of plants under continuous irrigation, regardless of the electrical conductivity of the irrigation water.

Losses in crop production were found when using irrigation waters with electrical conductivities lower than the salinity threshold $\left(3.2 \mathrm{dS} \mathrm{m}^{-1}\right)$ established for peanut crops, denoting the sensitivity of the cultivar BR-1 to salt stress.

Under the conditions of the present study, the use of brackish waters with electrical conductivities of up to $2.98 \mathrm{dS} \mathrm{m}^{-1}$ is viable for peanut production.

\section{ACKNOWLEDGMENTS}

The authors thank the Foundation for Support of Science and Technology of the State of Pernambuco (FACEPE) for granting a Master's scholarship to the first author; and the Coordination for the Improvement of Higher Education Personnel (CAPES) for the financial support for the research.

\section{REFERENCES}

ABUARAB, M. E.; EL-MOGY, M.; LOTFY, A. Response of green bean to pulse subsurface trickle irrigation. Misr Society of Agricultural Engineering, 28: 1-17, 2011.

ALMEIDA, W. et al. Yield of green beans subjected to continuous and pulse drip irrigation with saline water. Revista Brasileira de Engenharia Agrícola e Ambiental, 22: 476-481, 2018.

ALMEIDA, W. F.; LIMA, L. A.; PEREIRA, G. M. Drip pulses and soil mulching effect on american crisphead lettuce yield. Engenharia Agrícola, 35: 1009-1018, 2015.

AMERICAN PUBLIC HEALTH ASSOCIATION. Standard methods for examination of water and wastwater. 22. ed. Washington: American Public Health Association, 2012. 1360 p.

ARRUDA, I. M. et al. Crescimento e produtividade de cultivares e linhagens de amendoim submetidas a déficit hídrico. Pesquisa Agropecuária Tropical, 45: 146-154, 2015.

ARYA, S. S.; SALVE, A. R.; CHAUHAN, S. Peanuts as functional food: a review. Journal of Food Science and Technology, 53: 31-41, 2015.

ASSOULINE, S. et al. Soil-plant system response to pulsed drip irrigation and salinity. Soil Science Society of America Journal, 70: 1556-1568, 2006.

AYERS, R. S.; WESTCOT, D. W. A qualidade da água na agricultura. 2. ed. Campina Grande, $P B$ : UFPB, 1999. $153 \mathrm{p}$.

BORGES, A. L.; SILVA, D. J. Fertilizantes para fertirrigação. In: SOUSA, V. F. et al. (Eds.). Irrigação e fertirrigação em fruteiras e hortaliças. Brasília, DF: Embrapa Informação Tecnológica, 2011. v. 1, cap. 7. p. 253-264.

COMPANHIA NACIONAL DE ABASTECIMENTO - CONAB. Acompanhamento da safra brasileira de grãos. 7. ed. Brasília, DF: CONAB, 2020. $104 \mathrm{p}$.

CORREIA, K. G. et al. Crescimento, produção e características de fluorescência da clorofila a em amendoim sob condições de salinidade. Revista Ciência Agronômica, 40: 514-521, 2009.

EID, A. R.; BAKRY, B. A.; TAHA, M. H. Effect of pulse drip irrigation and mulching systems on yield, quality traits and irrigation water use efficiency of soybean under sandy soil conditions. Agricultural Sciences, 4: 249-261, 2013.

EMPRESA BRASILEIRA DE PESQUISA AGROPECUÁRIA - EMBRAPA. Amendoim BR-1: Informações para seu cultivo. 4. ed. Campina Grande, PB: Centro Nacional de Pesquisa de Algodão, 2009. 2 p.

EMPRESA BRASILEIRA DE PESQUISA AGROPECUÁRIA - EMBRAPA. Manual de métodos de análise de solo. 2. ed. Rio de Janeiro, RJ: Embrapa, 
$2011.212 \mathrm{p}$.

FERREIRA, D. F. Sisvar: A computer statistical analysis system. Ciência \& Agrotecnologia, 35: 1039-1042, 2011.

GRACIANO, E. S. A. et al. Crescimento e capacidade fotossintética da cultivar de amendoim BR-1 sob condições de salinidade. Revista Brasileira de Engenharia Agrícola e Ambiental, 15: 794-800, 2011.

HASANUZZAMAN, M. et al. Soybean production and environmental stresses. In: MIRANSARI, M. (Ed.). Environmental Stresses in Soybean Production. 1. ed. Londres, LN: Academic Press, 2016. v. 2, cap. 4, p. 61-102.

MANTOVANI, E. C.; BERNARDO, S.; PALARETTI, L. F. Irrigação: Princípios e métodos. 3. ed. Viçosa, MG: UFV, 2009, 318 p.

PAULUS, D. et al. Crescimento, consumo hídrico e composição mineral de alface cultivada em hidroponia com águas salinas. Revista Ceres, 59: 110-117, 2012.

RIBEIRO, A. C.; GUIMARÃES, P. T. G.; ALVAREZ, V. V. H. Recomendações para o uso de corretivos e fertilizantes em Minas Gerais: $5^{\text {a }}$ aproximação. 1. ed. Viçosa, MG: Comissão de Fertilidade do Solo do Estado de Minas Gerais, 1999. 280 p.

RICHARDS, L. A. Diagnosis and improvement of saline and alkali soils. Washington, D. C.: United States Salinity Laboratory, United States Department of Agriculture, 1954. 59 p. (Handbook, 60).

SÁ, F. V. S. et al. Tolerance of peanut (Arachis hypogea) genotypes to salt stress in the initial phase. Revista Brasileira de Engenharia Agrícola e Ambiental, 24: 37-43, 2020.

SANTOS, D. B. et al. Produção e parâmetros fisiológicos do amendoim em função do estresse salino. Idesia, 30: 69-74, 2012.

SANTOS, H. G. et al. Sistema Brasileiro de Classificação de Solos. 3. ed. Brasília, DF: Embrapa, 2013. 353 p.

SILVA, A. C. N. et al. Crescimento inicial do amendoinzeiro BR-1 irrigado com água salina. Revista Brasileira de Tecnologia Aplicada nas Ciências Agrárias, 8: 37-44, 2015.

SILVA, A. O. et al. Avaliação do desempenho de métodos de estimativa de evapotranspiração potencial para região norte de Recife-PE. Engenharia na
Agricultura, 20: 163-174, 2012.

SIZENANDO, C. I. T. et al. Agronomic efficiency of Bradyrhizobium in peanut under different environments in Brazilian Northeast. African Journal of Agricultural Research, 11: 3482-3487, 2016.

SOUSA, G. G. et al. Características agronômicas do amendoinzeiro sob irrigação com águas salinas em solo com biofertilizantes. Revista Agro@mbiente, 6: 124-132, 2012.

SOUSA, G. G. et al. Irrigação com Água salina na cultura do amendoim em solo com biofertilizante bovino. Nativa, 2: 89-94, 2014.

TAGLIAFERRE, C. et al. Produtividade e tolerância do feijão caupi ao estresse salino. Irriga, 23: 168179, 2018.

TAVARES, M. H. F. et al. Uso do forno de microondas na determinação da umidade em diferentes tipos de solo. Semina: Ciências Agrárias, 29: 529-538, 2009.

ZAMORA, V. R. O. et al. Pulse drip irrigation and fertigation water depths in the water relations of coriander. Horticultura Brasileira, 37: 22-28, 2019. 